\title{
CORRECTION
}

\section{Correction: A randomized controlled trial of an online health tool about Down syndrome}

Jeanhee Chung, MD, Karen Donelan, ScD, EdM, Eric A. Macklin, PhD, Alison Schwartz, MD, Ibrahim Elsharkawi, MD, Amy Torres, BS, Yichuan Grace Hsieh, PhD, RN, Holly Parker, BA, Stephen Lorenz, BA, Vasiliki Patsiogiannis, BA, Stephanie L. Santoro, MD, Mark Wylie, BA, Lloyd Clarke, BA, Greg Estey, BA, Sandra Baker, Patricia E. Bauer, BGS, Marilyn Bull, MD, Brian Chicoine, MD, Sarah Cullen, BA, Ariel Frey-Vogel, MD, MAT, Maureen Gallagher, MS, Reem Hasan, MD, PhD, Ashley Lamb, MD, MPH, Lisa Majewski, MSW, Jawanda Mast, MS, Travis Riddell, MD, MPH, Karen Sepucha, PhD, Melissa Skavlem, BA and Brian G. Skotko, MD, MPP iD

Genetics in Medicine (2021) 23:236; https://doi.org/10.1038/s41436-020-01033-5

Correction to: Genetics in Medicine 2020 https://doi.org/10.1038/ s41436-020-00952-7, published online 03 September 2020

In original version of the Article the Acknowledgements section omitted to include the contribution of DS-Connect ${ }^{\circledR}$ (The Down Syndrome Registry), which is supported by the Eunice Kennedy
Shriver National Institute of Child Health and Human Development (NICHD), National Institutes of Health (NIH), for the study recruitment used in this paper. This has now been added to both the PDF and HTML versions of the Article. 